\title{
Effect of Furosemide on Glucose Metabolism
}

\author{
By John M. Weller and Maria Borondy
}

The administration of furosemide, a benzothiadiazine analogue, to rats results in elevation of the initial and 2-hour postglucose loading blood glucose levels. Furosemide given to rats causes a decrease in the rate of glucose utilization by their adipose tissue in vitro. Furosemide added directly to the incubational medium also decreases the rate of glucose utilization of normal rats' fat tissue in vitro. These effects of furosemide are similar to those produced by chlorothiazide and other benzothiadiazine compounds. (Metabolism 16: No. 6, June, $532-536,1967$ )

$\mathbf{F}$ UROSEMIDE is a benzothiadiazine analogue having a furfuryl group substituted on the amino nitrogen of the anthranilic acid (Fig. 1). A favorable dose-response relationship results in furosemide having greater efficacy as a diuretic agent than currently available thiazides. ${ }^{1}$ The following experiments were carried out to ascertain if furosemide has an effect on glucose metabolism similar to that of chlorothiazide and other benzothiadiazine drugs. ${ }^{2}$

\section{Methods AND Results}

Three studies were carried out in order to determine: (1) if the administration of furosemide to rats alters their blood glucose concentrations, both before and after glucose loading, (2) if furosemide given to rats decreases the rate of utilization of glucose in vitro by their fat tissue; and (3) if the presence of furosemide in an in vitro system decreases the rate of utilization of glucose by normal rats' adipose tissue.

\section{Glucose Tolerance Tests on Rats}

Male Sprague-Dawley rats were given $100 \mathrm{mg}$. furosemicle $/ \mathrm{Kg}$. body weight $/ \mathrm{day}$ in drinking water for 2 weeks. Similar rats were given tap water to drink. At the end of 2 weeks oral glucose tolerance tests were done on each of the rats by giving them $1.75 \mathrm{Gm}$. glucose/Kg. body weight through a stomach tube. Blood was obtained by clipping the tail and glucose determinations were done by the Nelson-Somogyi method.3 Results are shown in Table 1. Mean glucose values were significantly higher for both initial ( $\mathrm{p}<0.02$ $>0.01$ ) and 2-hour postglucose loading blood samples ( $p<0.001$ ) for rats which had been given furosemide compared to the respective blood glucose levels of control animals on tap water. The differences from the control values of the mean blood glucose concentrations at $1 / 2,1$, and $1 \frac{1}{2}$ hours after giving glucose to the rats receiving furosemide did not reach the level of statistical significance, however, and are not shown.

From the Department of Internal Medicine, The University of Michigan, Ann Arbor, Michigan.

This work was supported by grants from the Michigan Heart Association, USPHS \#HE08083-03 from the NIH, and Hoechst Pharmaceuticals, Inc.

Received for publication Dec. 1, 1966.

Johx M. Weller, M.D.: Professor of Internal Medicine, The University of Michigan. Maris Bonondy: Laboratory Technologist, Dept. of Internal Medicine, The University of Michigan. 
<smiles>Nc1cc(C(=O)O)c(NCc2ccco2)cc1Cl</smiles><smiles>NS(=O)(=O)c1cc2c(cc1Cl)N=CNO2</smiles><smiles>CC1=Nc2ccc(Cl)cc2SN1</smiles>

4-Chioro-N-Furfuryl-5Sulfamoyionthranilic Acid

6-Chloro-2H-1,2, 4 Benzothiodiozine - $7-$
Sulfonomide 1, 1- Dioxide

Fig. 1.-The chemical structures and formulas of 3 benzothiadiazine derivatives which interfere with glucose metabolism.

Table 1.-Blood Glucose Values during Oral Glucose Tolerance Tests on Rats

\begin{tabular}{lrrrr}
\hline & Normal Rats (27) & & \multicolumn{2}{c}{ Furosemide Rats (28) } \\
\hline Time (hours) & 0 & 2 & 0 & 2 \\
Mean & 106 & 111 & 113 & 128 \\
\pm S.D. & 12 & 9 & 8 & 11 \\
\hline
\end{tabular}

Number of animals in parenthesis. Glucose values expressed as $\mathrm{mg} . / 100 \mathrm{ml}$. blood.

\section{Glucose Utilization In Vitro of Adipose Tissue from Rats Receiving Furosemide}

Male Sprague-Dawley rats weighing 220 to $260 \mathrm{Gm}$. were divided into 3 groups. One group was subdivided and given either 10 or $100 \mathrm{mg}$. furosemide/Kg. body weighl/day; one was given $10 \mathrm{mg}$. hydrochlorothiazide/ $\mathrm{Kg}$. body weight/day, and the third group served as controls. Drugs were given in drinking water. At the end of 2 weeks the nonfasting rats were decapitated, epididymal fat pads removed and the peripheral $5 \mathrm{~mm}$. of each was cut into 8 pieces. Four pieces of fat pad, each from a different rat, but of the same group, were placed in a tared flask containing $3 \mathrm{ml}$. chilled, modified Krebs' bicarbonate buffer solution, previously equilibrated with 5 per cent $\mathrm{CO}_{2}-95$ per cent $\mathrm{O}_{2}$, containing $200 \mathrm{mg}$. glucose $/ 100 \mathrm{ml}$, and 0.25 units crystalline insulin ${ }^{*}$ and $2 \mathrm{mg}$. gelatin $/ \mathrm{ml}$. Flasks were shaken for 2 hours at $37 \mathrm{C}$., then flasks plus tissues were weighed. Media glucose determinations before and after incubation were done by the Nelson-Somogyi method."

Results are shown in Table 2. The adipose tissue of rats receiving either 10 (Exp. 1 and 2) or 100 (Exp. 3 and 4) $\mathrm{mg}$. furosemide/ $\mathrm{Kg}$. body weight/day for 2 weeks utilized significantly less glucose than did that from normal rats $(\mathrm{p}<0.02>0.01$ for $10 \mathrm{mg}$. $/ \mathrm{Kg}$. dose and $<0,001$ for $100 \mathrm{mg}$. $/ \mathrm{Kg}$. dose). Hydrochlorothiazide given to rats also produced a significant decrease in the rate of utilization of glucose by their epididymal fat tissue as compared to that of normal rats in each of the 2 series of experiments $(\mathrm{p}<0.01>0.001$ and $<0.001)$. The administration of both dosage levels of furosemide to rats appeared to exert an inhibitory effect on glucose utilization by their adipose tissues of approximately the same magnitude. This inhibitory action of furosemide was similar to that elicited by giving rats $10 \mathrm{mg}$. hydrochlorothiazide $/ \mathrm{Kg}$. body weight/day for 2 weeks.

${ }^{*}$ Kindly supplied by Eli Lilly and Co. 
Table 2.-Glucose Disappearance Rates from Media Containing Epididymal Fat Pads of Control Rats and Rats Given Hydrochlorothiazide or Furosemide

\begin{tabular}{|c|c|c|c|c|c|c|c|}
\hline Exp. No. & $\begin{array}{c}\text { Control } \\
\text { Rats }\end{array}$ & $\begin{array}{l}\text { Hydrochloro- } \\
\text { thiazide Rats }\end{array}$ & $\begin{array}{c}\text { Furosemide } \\
\text { Rats } \\
\text { (10 mg./ } \\
\text { Kg.) }\end{array}$ & $\begin{array}{l}\text { Exp. } \\
\text { No. }\end{array}$ & $\begin{array}{c}\text { Control } \\
\text { Rats }\end{array}$ & $\begin{array}{l}\text { Hydrochloro- } \\
\text { thiazide Rats }\end{array}$ & $\begin{array}{c}\text { Furosemide } \\
\text { Rats } \\
(100 \mathrm{mg} . / \\
\text { Kg. }) \\
\end{array}$ \\
\hline \multirow[t]{12}{*}{1} & 4.25 & 4.66 & 4.89 & 3 & 5.51 & 4.59 & 4.59 \\
\hline & 4.00 & 3.61 & 3.75 & & 5.72 & 3.7 .3 & 3.3 .3 \\
\hline & 3.87 & 3.26 & 3.76 & & 4.89 & 2.32 & 3.72 \\
\hline & 4.59 & 4.68 & 3.88 & & 4.96 & 1.95 & 4.60 \\
\hline & 5.18 & 4.33 & 5.24 & & 5.67 & 3.61 & 3.80 \\
\hline & 4.84 & 3.22 & 3.97 & & 5.12 & 2.52 & 2.76 \\
\hline & 4.49 & 3.9 .3 & 5.81 & & 4.56 & 3.14 & 3.17 \\
\hline & 5.73 & 3.84 & 4.31 & & 4.49 & 3.21 & 2.9 .3 \\
\hline & 4.26 & 4.08 & 4.16 & & 5.02 & 3.05 & 2.34 \\
\hline & 4.19 & 3.29 & 3.60 & & 4.51 & 4.66 & 4.74 \\
\hline & 5.65 & 4.23 & 2.03 & & 4.48 & 2.14 & 3.53 \\
\hline & 4.59 & 3.81 & 3.65 & & 6.35 & 3.44 & 3.42 \\
\hline \multirow[t]{12}{*}{2} & 4.16 & 3.40 & 1.33 & 4 & 6.01 & 3.16 & 4.07 \\
\hline & 3.38 & 2.28 & 2.72 & & 5.36 & 2.76 & 2.74 \\
\hline & 3.05 & 3.64 & 2.11 & & 6.14 & 4.81 & 4,06 \\
\hline & 3.49 & 3.94 & - & & 4.03 & 3.08 & 4.39 \\
\hline & 5.64 & 3.84 & 2.68 & & 6.27 & 2.85 & 4.93 \\
\hline & 3.20 & 3.58 & 3.18 & & 6.27 & 3.41 & 4.22 \\
\hline & 3.01 & 3.12 & 3.50 & & 7.26 & 4.16 & 3.65 \\
\hline & 2.97 & 2.64 & 2.42 & & 5.73 & 4.45 & - \\
\hline & 3.46 & 4.19 & 3.20 & & 4.97 & 4.5 .3 & 4.99 \\
\hline & 4.33 & 4.52 & 3.38 & & 5.13 & 4.79 & 3.46 \\
\hline & 5.46 & 3.00 & 4.41 & & 5.14 & 3.88 & 3.57 \\
\hline & 3.49 & 2.49 & 3.56 & & 6.63 & 2.39 & 4.01 \\
\hline Nean & 4.22 & 3.65 & 3.55 & Meinn & 5.43 & 3.44 & 3.78 \\
\hline \pm S.D. & 0.85 & 0.64 & 1.02 & $\pm S, 1)$. & 0.71 & 0.87 & 0.78 \\
\hline
\end{tabular}

Values express the rate of decrease of glucose from the medium as mg./Gm. wet tissue/2 hrs. Each value represents a separate incubating flask.

\section{Glucose Utilization In Vitro of Normal Rats' Adipose Tissue uith Furoscmide Present in the Medium}

Epididymal fat pads from normal rats were handled in a manner similar to the study described above except that the in vitro system contained no insulin or gelatin. One-half of the flasks contained furosemide in a concentration of $1 \times 10^{-3}$ molar in the incubational media. The mean glucose disappearance rates of 5 separate experiments, as well ils those of a sixth experiment done at a later date, are shown in Table 3. The presence of furosemide in the medium caused a significant decrease in these mean rates of glucose ntilization in vitro by adipose tissue ( $\mathrm{p}<0.01>0.001$ for both) as compared to the rates when no furosemide was present. In an additional experiment of similar design the in vitro effect of furosemide in the medium was compared to that of chlorothiazide when present in the same concentration of $1 \times 10^{-3}$ molar (Table 4). The inhibitory effects of these drugs on glucose utilization in vitro by normal fat tissue are of the same order of magnitude: both furosemide and chlorothiazide causing a similax diminution in the rate of glucose utilization as compared to the normal $(p<0.05>0.02$ for furosemide and $<0.01>0.001$ for ('hlorothiazide). 
Table 3.-Glucose Disappearance Rates from Media Containing Normal Rats' Epididymal Fat Pads with and without Furosemide in the Medium

\begin{tabular}{clcc}
\hline Exp. No. & & $\begin{array}{c}\text { Furosemide } \\
\left(1 \times 10^{-3} \text { molar }\right)\end{array}$ & No Furosemide \\
\hline 1 to 5 & Mean & $4.74(29)$ & $6.03(26)$ \\
& IS.D. & 1.29 & 1.64 \\
6 & Mean & $2.40(11)$ & $3.67(12)$ \\
& ES.D. & 0.73 & 0.77 \\
\hline
\end{tabular}

Values express the rate of disappearance of glucose from the medium as mg./Gm. wet tissue/2 hrs. Number of flasks in parenthesis.

Table 4.-Glucose Disappearance Rates from Media Containing Normal Rats' Epididymal Fat Pads when Furosemide or Chlorothiazide is Added to the Medium

\begin{tabular}{|c|c|c|c|}
\hline & $\begin{array}{c}\text { Furosemide } \\
\left(1 \times 10^{-3} \text { molar }\right)\end{array}$ & $\begin{array}{c}\text { Chlorothiazide } \\
\left(1 \times 10^{-3} \text { molar }\right)\end{array}$ & Control \\
\hline & 2.39 & 2.99 & 3.48 \\
\hline & 2.72 & 6.47 & 5.68 \\
\hline & 6.22 & 3.09 & 4.62 \\
\hline & 8.99 & 1.68 & 6.56 \\
\hline & 2.33 & 5.04 & 8.80 \\
\hline & 2.94 & 5.37 & 7.85 \\
\hline & 5.53 & 5.65 & 7.10 \\
\hline & 2.60 & 5.01 & 8.68 \\
\hline & 4.97 & 4.83 & 8.39 \\
\hline & 7.06 & 2.46 & 4.46 \\
\hline & 4.16 & 2.80 & 3.99 \\
\hline & 3.72 & 4.10 & - \\
\hline Mean & 4.47 & 4.12 & 6.33 \\
\hline \pm S.D. & 2.04 & 1.42 & 1.89 \\
\hline
\end{tabular}

Values express the rate of decrease of glucose from the medium as $\mathrm{mg} . / \mathrm{Gm}$. wet tissue $/ 2$ hrs. Each value represents a separate incubating flask.

\section{Discussron}

Furosemide has an effect on carbohydrate metabolism which qualitatively is similar to that of chlorothiazide, diazoxide and other thiazides. ${ }^{2}$ These drugs appear to exert their inhibitory action on glucose utilization through several mechanisms. It has been demonstrated in patients that thiazides decrease the level of serum insulin-like activity. ${ }^{4}$ This in turn probably interferes with the cellular entry of glucose in those tissues where glucose transport into the cell is facilitated by insulin. Thiazides given to rats also cause a decrease in the activities of their liver glucokinase and dihydroxyacetone-kinase, ${ }^{5}$ enzymes which require insulin for their synthesis, thereby decreasing the rate of phosphorylation of glucose and dihydroxyacetone. This would appear to be another result of the lowered level of insulin-like activity. An additional action of thiazide drugs on carbohydrate metabolism is demonstrated when chlorothiazide, added directly to the incubating medium, 
decreases the in vitro rate of utilization of glucose by normal rats adipose tissue. ${ }^{6}$ Furosemide has a similar action. This direct effect of these drugs on the rate of glucose utilization of fat tissue is apart from their ability to lower the level of serum insulin-like activity and represents a direct inhibitory action on some phase of glucose metabolism.

It is of interest that furosemide alters carbohydrate metabolism in a manner similar to that produced by chlorothiazide and diazoxide. The structures of chlorothiazide and diazoxide are similar, both having dioxide at the 1 position (Fig. 1). This is lacking in furosemide which has instead a sulfamoyl group which it shares in common with chlorothiazide, but which is not part of the diazoxide molecule. It is possible that the carboxyl group in furosemide functionally serves in place of the dioxide. Clinically diazoxide appears to be a rather potent hyperglycemic agent, ${ }^{4}$ while furosemide seems to cause less hyperglycemia in patients than do the commonly used thiazide diuretics. ${ }^{7}$ Abnormal elevation of the blood sugar on glucose tolerance testing related to furosemide administration does occur, however. ${ }^{8}$ Perhaps the lesser degree of disturbance of glucose metabolism by furosemide is related to its shorter duration of action, as judged by its diuretic activity, thus allowing more time free from its effect on carbohydrate metabolism. The basic mechanisms of action of furosemide on glucose utilization, however, appear to be similar to those of chlorothiazide and other benzothiadiazine drugs.

\section{REFERENCES}

1. Hutcheon, D. E., Mehta, D., and Romano, A.: Diuretic action of furosemide. Arch. Int. Med. 115:542, 1965.

2. Weller, J. M., and Borondy, P. E.: Effects of benzothiadiazine drugs on carbohydrate metabolism. Metabolism 14: $708,1965$.

3. Nelson, N.: Photometric adaptation of Somogyi method for determination of glucose. J. Biol. Chem. 153:375, 1944.

4. Dollery, C. T., Pentecost, B. L., and Samaan, N. A.: Drug-induced diabetes. Lancet 2:735, 1962.

5. Borondy, P. E., and Weller, J. M.: Effect of chlorothiazide on rat liver gluco- kinase, hexokinase and dihydroxyacetone-kinase activities. Proc. Soc. Exper. Biol. \& Med. 118:938, 1965.

6. Weller, J. M., and Borondy, M.: Inhibitory effect of chlorothiazide in vitro on glucose metabolism of adipose tissue. Proc. Soc. Exper. Biol. \& Med. in press.

7. Reubi, F. C.: Clinical use of furosemide. Presented at the Conference on the Physiology of Diuretic Agents, The New York Academy of Sciences, New York, March 3-5, 1966.

8. Toivonen. S., and Mustala, O.: Diabetogenic action of frusemide. Brit. Med. J. 1:920, 1966. 